\title{
SSX2 Positive
}

National Cancer Institute

\section{Source}

National Cancer Institute. SSX2 Positive. NCI Thesaurus. Code C148638.

An indication that SSX2 expression has been detected in a sample. 